\title{
Recent Distribution Records of the Little Brown Bat, Myotis lucifugus, in Manitoba and Northwestern Ontario
}

\author{
JoHn E. Dubois ${ }^{1,2}$ and KIMBERLY M. MONSON ${ }^{3}$ \\ ${ }^{1}$ Natural History Division, The Manitoba Museum, 190 Rupert Avenue, Winnipeg, Manitoba R3B 0N2 Canada \\ ${ }^{2}$ Present address: Wildlife and Ecosystem Protection Branch, Manitoba Conservation, Box 24, 200 Saulteaux Crescent, Winnipeg, \\ Manitoba R3J 3W3 \\ ${ }^{3}$ Geography Department, University of Winnipeg, 515 Portage Avenue, Winnipeg, Manitoba R3B 2E9 Canada
}

Dubois, John E., and Kimberly M. Monson. 2007. Recent distribution records of the Little Brown Bat, Myotis lucifugus, in Manitoba and northwestern Ontario. Canadian Field-Naturalist 121(1): 57-61.

Until recently, the distribution of the Little Brown Bat (Myotis lucifugus) in Manitoba and northwestern Ontario was poorly documented. Since 1988, we have been banding and recapturing little browns throughout Manitoba and adjacent Lake of the Woods region in Ontario. All known hibernacula in the study area are recorded here for the first time, along with time of emergence. Connections between some hibernacula and summer nurseries are verified by band returns, ranging from 37 to $540 \mathrm{~km}$.

Key Words: Little Brown Bat, Myotis lucifugus, distribution, Manitoba, northwestern Ontario.

We began our study of the Little Brown Bat (Myotis lucifugus) in 1988. The objectives of the study were: (1) to map the distribution of Little Brown Bats in Manitoba; (2) to find as many hibernacula and summer nursery roosts as possible; (3) to learn where bats found in hibernacula spend the summer; and (4) where bats found in summer roosts spend the winter. An overriding objective has been to encourage awareness and conservation of bats among the public and responsible agencies in Manitoba. All work was done under Manitoba Conservation "Wildlife Scientific Research", "Ecological Reserves Research", and Ontario Ministry of Natural Resources (Kenora District) permits issued to Dubois.

Little previous research had been done on the six species of bats known to occur in Manitoba (Banfield 1974). Robert Barclay worked on some species and made incidental observations of occurrences and migration dates of little browns at the University of Manitoba Delta Marsh Field Station from 1981 to 1983 (Barclay 1984). Barclay (1993) stressed "Even for species that are well studied elsewhere, such as the Little Brown Bat, information about the biology of prairie populations is scarce. More than anything else, it is this lack of information that hinders conservation efforts for prairie bats." This study is meant to aid conservation efforts by filling gaps in our knowledge.

A. L. Rand (1948) reported sightings of the Little Brown Bat in the Flin Flon district. J. Dewey Soper (1961) reported the first specimens taken at Max Lake, in Turtle Mountain Provincial Park, 20 August 1949. Little browns were reported from the Delta area (Tamsitt 1962). In 1978 the late Walter Cook of Grand Rapids showed provincial biologist Bill Koonz a couple of caves north of the town that over-wintered bats (Koonz, Manitoba Conservation, personal communication). Since 1988 systematic searching for caves with the Speleological Society of Manitoba (SSM) has pro- duced more information on the Little Brown Bat in Manitoba. Soliciting the public and various agencies to report caves, summer bat roosts and sightings has also been very productive.

\section{Methods}

We banded Little Brown Bats to monitor their distribution and seasonal movements. Plastic coloured bands were used in the first year of banding, 1988. Each cave or location was identified by a different colour. For more precise tracking of individual bats and their movements, numbered aluminium bands (National Band \& Tag Co., Kentucky), size 2 were used in 1989 and thereafter.

Hibernacula were located with the aid of the considerable efforts of the members of the Speleological Society of Manitoba and other volunteers. Starting from reported hibernacula sites, the authors and other members of the SSM used a combination of surficial geology, topographic maps, and air photos to identify likely areas for methodical ground searches. Karst features such as caves, sinkholes and trenches were detected on air photos in areas where limestone, dolomite and gypsum bedrock are near the surface. These areas were then visited and searched in a grid pattern, using map and compass, and latterly, hand-held global positioning system (GPS) units.

Information provided by home and cottage owners, Manitoba Department of Conservation, Ontario Ministry of Natural Resources, and other agencies led to the banding of bats in residential and cottage summer nursery colonies throughout the province, spilling over into adjacent northwestern Ontario around the north end of Lake of the Woods.

Greatest frequency of banding occurred in caves in the Grand Rapids and Gypsumville areas, and in one large cave (St. George Cave) north of Hodgson. [See map, Figure 1] The karst features, where the caves are found in gypsum and dolomite formations of these areas, are 
described in detail in the field reports of the Manitoba Mines Branch for 1988, 1989 and 1990 (e.g., Sweet et al. 1988) and in McRitchie and Monson (2000).

We used standard techniques to capture and band the bats (Kunz and Kurta 1988). We captured them in caves by plucking the torpid bats carefully by hand from the cave wall, and placing them in a cloth bag. We live-trapped Little Brown Bats with a harp trap (Tuttle 1974). Once captured, the bats were examined to determine sex, reproductive status, age, injuries (both healed and fresh), and, on a cursory basis, external parasites present. According to custom (Kunz and Kurta

TABLE 1. Hibernacula banding locations in Manitoba and northwestern Ontario for Little Brown Bats.

\begin{tabular}{lcc}
\hline \hline Location & Latitude & Longitude \\
\hline Cook's Cave [GR] & $53^{\circ} 26^{\prime} 10^{\prime \prime} \mathrm{N}$ & $99^{\circ} 32^{\prime} 10^{\prime \prime} \mathrm{W}$ \\
Dale's Cave [GR] & $53^{\circ} 39^{\prime} 32^{\prime \prime} \mathrm{N}$ & $99^{\circ} 26^{\prime} 19^{\prime \prime} \mathrm{W}$ \\
Firecamp Cave [GR] & $53^{\circ} 29^{\prime} 25^{\prime \prime} \mathrm{N}$ & $99^{\circ} 20^{\prime} 50^{\prime \prime} \mathrm{W}$ \\
Fold Cavern [Gyp] & $51^{\circ} 51^{\prime} 02^{\prime \prime N}$ & $98^{\circ} 29^{\prime} 30^{\prime \prime} \mathrm{W}$ \\
Iguana Crypt [GR] & $53^{\circ} 26^{\prime} 14^{\prime \prime} \mathrm{N}$ & $99^{\circ} 30^{\prime} 58^{\prime \prime} \mathrm{W}$ \\
Longcrawl Cave [Gyp] & $51^{\circ} 47^{\prime} 10^{\prime \prime} \mathrm{N}$ & $98^{\circ} 37^{\prime} 00^{\prime \prime} \mathrm{W}$ \\
Microwave Cave [GR] & $53^{\circ} 34^{\prime} 05^{\prime \prime} \mathrm{N}$ & $99^{\circ} 26^{\prime} 25^{\prime \prime} \mathrm{W}$ \\
Squeaky Cave [GR] & $53^{\circ} 37^{\prime} 42^{\prime \prime} \mathrm{N}$ & $99^{\circ} 20^{\prime} 31^{\prime \prime} \mathrm{W}$ \\
St. George Cave [Hod] & $51^{\circ} 36^{\prime} 07^{\prime \prime N}$ & $97^{\circ} 24^{\prime} 52^{\prime \prime} \mathrm{W}$ \\
Stormcloud Cave [Gyp] & $51^{\circ} 50^{\prime} 28^{\prime \prime} \mathrm{N}$ & $98^{\circ} 29^{\prime} 40^{\prime \prime} \mathrm{W}$ \\
Richard Lake, Ont. [LW] & $49^{\circ} 50^{\prime} 54^{\prime \prime} \mathrm{N}$ & $94^{\circ} 41^{\prime} 30^{\prime \prime} \mathrm{W}$ \\
Abyss Cave [GR] & $53^{\circ} 42^{\prime} 55^{\prime \prime} \mathrm{N}$ & $99^{\circ} 25^{\prime} 40^{\prime \prime} \mathrm{W}$ \\
Okaw Cave [GR] & $53^{\circ} 51^{\prime} 53^{\prime \prime} \mathrm{N}$ & $100^{\circ} 07^{\prime} 12^{\prime \prime} \mathrm{W}$ \\
\hline \hline
\end{tabular}

$[\mathrm{GR}]=$ Grand Rapids area; [Gyp] = Gypsumville area; [Hod $]$ = Hodgson area; [Wh] = Whiteshell area; [LW] = Lake of the Woods

TABLE 2. Summer nursery colony banding locations in Manitoba and northwestern Ontario for Little Brown Bats.

\begin{tabular}{lcc}
\hline \hline Location & Latitude & Longitude \\
\hline Brereton Lake, Manitoba & $49^{\circ} 54^{\prime} 16^{\prime \prime} \mathrm{N}$ & $95^{\circ} 32^{\prime} 40^{\prime \prime} \mathrm{W}$ \\
Caliper Lake Provincial Park, Ontario & $49^{\circ} 03^{\prime} 42^{\prime \prime N}$ & $93^{\circ} 54^{\prime} 46^{\prime \prime} \mathrm{W}$ \\
Deleau, Manitoba & $49^{\circ} 34^{\prime} 52^{\prime \prime} \mathrm{N}$ & $100^{\circ} 34^{\prime} 31^{\prime \prime} \mathrm{W}$ \\
French Portage Narrows, Ontario & $49^{\circ} 26^{\prime} 58^{\prime \prime} \mathrm{N}$ & $94^{\circ} 40^{\prime} 14^{\prime \prime} \mathrm{W}$ \\
Grand Rapids, Manitoba & $53^{\circ} 12^{\prime} 30^{\prime \prime} \mathrm{N}$ & $99^{\circ} 18^{\prime} 00^{\prime \prime} \mathrm{W}$ \\
Jackfish Lake, Manitoba & $50^{\circ} 18^{\prime} 05^{\prime \prime} \mathrm{N}$ & $100^{\circ} 02^{\prime} 10^{\prime \prime} \mathrm{W}$ \\
Keewatin, Ontario & $49^{\circ} 45^{\prime} 33^{\prime \prime} \mathrm{N}$ & $94^{\circ} 33^{\prime} 20^{\prime \prime} \mathrm{W}$ \\
Melita, Manitoba & $49^{\circ} 16^{\prime} 05^{\prime \prime} \mathrm{N}$ & $100^{\circ} 59^{\prime} 45^{\prime \prime} \mathrm{W}$ \\
Moosehorn, Manitoba & $51^{\circ} 17^{\prime} 29^{\prime \prime} \mathrm{N}$ & $98^{\circ} 25^{\prime} 22^{\prime \prime} \mathrm{W}$ \\
Pebble Beach, Manitoba & $50^{\circ} 59^{\prime} 34^{\prime \prime} \mathrm{N}$ & $98^{\circ} 26^{\prime} 53^{\prime \prime} \mathrm{W}$ \\
Rush Bay, Lake of the Woods, Ontario & $49^{\circ} 39^{\prime} 55^{\prime \prime N}$ & $94^{\circ} 53^{\prime} 28^{\prime \prime} \mathrm{W}$ \\
Rushing River Provincial Park, Ontario & $49^{\circ} 41^{\prime} 13^{\prime \prime} \mathrm{N}$ & $94^{\circ} 13^{\prime} 44^{\prime \prime} \mathrm{W}$ \\
Schist Lake, Manitoba & $54^{\circ} 39^{\prime} 45^{\prime \prime} \mathrm{N}$ & $101^{\circ} 48^{\prime} 19^{\prime \prime} \mathrm{W}$ \\
Sherridon, Manitoba & $55^{\circ} 07^{\prime} 26^{\prime \prime N}$ & $101^{\circ} 05^{\prime} 12^{\prime \prime} \mathrm{W}$ \\
Wasagaming, Manitoba & $50^{\circ} 39^{\prime} 30^{\prime \prime} \mathrm{N}$ & $99^{\circ} 58^{\prime} 07^{\prime \prime} \mathrm{W}$ \\
Wekusko Falls, Manitoba & $54^{\circ} 47^{\prime} 22^{\prime \prime N}$ & $99^{\circ} 58^{\prime} 21^{\prime \prime} \mathrm{W}$ \\
\hline \hline
\end{tabular}

TABLE 3. Additional Little Brown Bat locations in Manitoba and northwestern Ontario verified by the authors.

\begin{tabular}{lcc}
\hline \hline Location & Latitude & Longitude \\
\hline Souris, Manitoba & $49^{\circ} 37^{\prime} 02^{\prime \prime} \mathrm{N}$ & $100^{\circ} 15^{\prime} 37^{\prime \prime} \mathrm{W}$ \\
Reston, Manitoba & $49^{\circ} 33^{\prime} 27^{\prime \prime} \mathrm{N}$ & $101^{\circ} 05^{\prime} 36^{\prime \prime} \mathrm{W}$ \\
Minnedosa, Manitoba & $50^{\circ} 14^{\prime} 43^{\prime \prime} \mathrm{N}$ & $99^{\circ} 50^{\prime} 34^{\prime \prime} \mathrm{W}$ \\
Falcon Lake, Manitoba & $49^{\circ} 41^{\prime} 11^{\prime \prime N}$ & $95^{\circ} 14^{\prime} 54^{\prime \prime} \mathrm{W}$ \\
Deception Lake, Ontario & $49^{\circ} 44^{\prime} 27^{\prime \prime} \mathrm{N}$ & $94^{\circ} 50^{\prime} 33^{\prime \prime} \mathrm{W}$ \\
Setting Lake, Manitoba & $55^{\circ} 04^{\prime} 11^{\prime \prime} \mathrm{N}$ & $98^{\circ} 29^{\prime} 46^{\prime \prime} \mathrm{W}$ \\
Woodridge, Manitoba & $49^{\circ} 17^{\prime} 02^{\prime \prime} \mathrm{N}$ & $96^{\circ} 08^{\prime} 52^{\prime \prime} \mathrm{W}$ \\
vicinity of Oak Lake, Manitoba & $49^{\circ} 40^{\prime} 17^{\prime \prime} \mathrm{N}$ & $100^{\circ} 37^{\prime} 34^{\prime \prime} \mathrm{W}$ \\
Kerr's Lake, Manitoba & $50^{\circ} 30^{\prime} 00^{\prime \prime N}$ & $99^{\circ} 40^{\prime} 57^{\prime \prime} \mathrm{W}$ \\
Pointe du Bois, Manitoba & $50^{\circ} 18^{\prime} 03^{\prime \prime} \mathrm{N}$ & $95^{\circ} 33^{\prime} 05^{\prime \prime} \mathrm{W}$ \\
Otter Falls, Manitoba & $50^{\circ} 08^{\prime} 48^{\prime \prime N}$ & $95^{\circ} 48^{\prime} 38^{\prime \prime} \mathrm{W}$ \\
Taiga Biological Station, Wallace Lake, Manitoba & $51^{\circ} 02^{\prime} 40^{\prime \prime} \mathrm{N}$ & $95^{\circ} 20^{\prime} 40^{\prime \prime} \mathrm{W}$ \\
Winnipeg, Manitoba & $49^{\circ} 53^{\prime} 04^{\prime \prime N}$ & $97^{\circ} 08^{\prime} 47^{\prime \prime} \mathrm{W}$ \\
\hline \hline
\end{tabular}




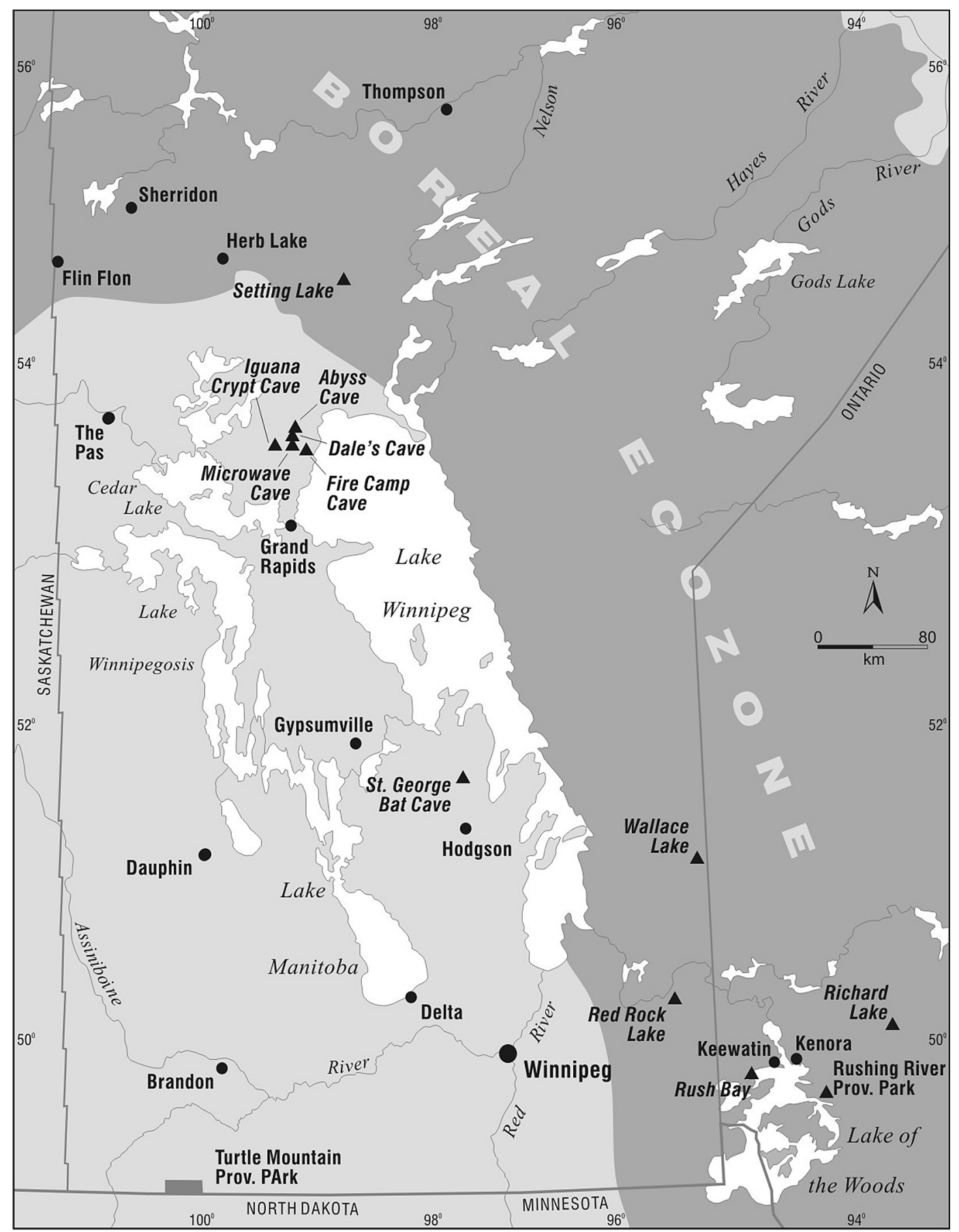

FIGURE 1. Map of Manitoba showing the portion of the Boreal Ecozone and major settlements. Circles are settlements, triangles are other localities (see text). 
1988), we banded males on the right forearm and females on the left. Those bats found to be previously banded were duly recorded and injuries and/or parasites noted. Time in capture and handling was kept to a minimum to avoid stressing the animals. Banding locations are summarized in Tables 1 and 2, below.

Many of the Manitoba caves containing bats were mapped, the annual maximum and minimum temperatures recorded (average $+5^{\circ} \mathrm{C}$ ) and any other vertebrate or invertebrate inhabitants noted, by us, other SSM members, and by staff of the Manitoba Museum and the Manitoba Geological Survey. These details and more on the caves and surrounding landscapes are thoroughly described in McRitchie and Monson (2000).

\section{Results}

To date we have banded more than 9000 Little Brown Bats. J. Dewey Soper (1961) speculated that Little Brown Bats "probably extend almost to the Hudsonian Zone", now called the Boreal Shield ecozone (Ecological Stratification Working Group 1995), while van Zyll de Jong (1985) stated: "It is found from the Atlantic to the Pacific coast and occurs to the limits of the boreal forest."

In addition to those locations where banding has taken place (Tables 1 and 2), we have verified the presence of this species throughout southern Manitoba and at least to the latitude of Taiga Biological Station, University of Manitoba, Wallace Lake $\left(51^{\circ} 01^{\prime} 50 " \mathrm{~N}\right)$, east of Lake Winnipeg (Table 3). On the west side of the province, Little Brown Bats occur to the latitude of Sherridon $\left(55^{\circ} 07^{\prime} 26^{\prime \prime} \mathrm{N}\right)$, and in north-central parts of the province to Setting Lake $\left(55^{\circ} 04^{\prime} 11^{\prime \prime N}\right)$ (Table 3) - locations slightly north and just south of Herb Lake (reported in van Zyll de Jong 1985, page 70).

Similar to many species across Canada, a combination of degree-days and night-length likely constrains their range in the north - see discussions in Holroyd et al. (1994), Nagorsen and Brigham (1993), Humphries et al. (2002). A maternity roost of Little Brown Bats was reported recently at $58^{\circ} 06^{\prime} 36^{\prime \prime} \mathrm{N}$ on the Alaskan coast (Parker and Cook 1996), as was one at Squanga Lake, Yukon at $60^{\circ} 28^{\prime} 40^{\prime \prime} \mathrm{N}$ (Jung and Slough 2005) .

Sherridon $\left(55^{\circ} 07^{\prime} 26^{\prime \prime} \mathrm{N}\right)$ is the site of the northernmost nursery colony we have found in Manitoba to date, while Okaw Cave $\left(53^{\circ} 51^{\prime} 53^{\prime \prime} \mathrm{N}\right)$ is the northernmost hibernaculum. Individual Little Brown Bats have been reported during summers from as far north as Thompson (55'44'36"N). Little browns have been reported to us as showing up at summer nursery colonies in central and southern Manitoba as early as the last week in April, and more often, the first week of May. However, we routinely find large numbers of a given hibernaculum still in torpor when entering the caves in the Grand Rapids area on the Victoria Day long weekend in May (normally the third weekend of the month, range 17-28 May).

Band returns from this study have shown little browns are very loyal to both their summer and winter roosts, with very low incidences of transference $(>1 \%)$. Recoveries from subsequent, different roosts ranged from $5 \mathrm{~km}$ to $533 \mathrm{~km}$ distant from point of original banding. Seasonal migration distance from hibernacula to summer nursery colony for adult females ranged from $37 \mathrm{~km}$ to $540 \mathrm{~km}$. Details of inter-roost and seasonal movements will be published separately.

We started banding Little Brown Bats around Lake of the Woods (mainly in the Kenora area) in 1993 to learn whether those populations use Manitoba caves to hibernate. Band returns demonstrate that at least some of those females forming nursery colonies in that region definitely use central Manitoba caves to over-winter, as well as one nearby abandoned mine. It has been speculated for some time that abandoned mines in the Kenora area have served as hibernacula (Nagorsen 1980). In July 1995, we were directed to an abandoned mine at Richard Lake, $37 \mathrm{~km}$ east of Kenora and, upon returning in late September, found it to contain at least 250 Little Brown Bats, none previously banded. In the Richard Lake hibernaculum in subsequent years we recaptured banded bats from nursery colonies on Lake of the Woods (Keewatin, French Portage Narrows, Rushing River Provincial Park), as well as bats previously banded in Manitoba hibernacula as far as $533 \mathrm{~km}$ away (St. George, Iguana Crypt and Microwave caves).

\section{Conservation}

This study has verified that at least 11 caves in Manitoba and one abandoned mine in northwestern Ontario serve as hibernacula for Little Brown Bats (Table 1). Bats of many species are at their most vulnerable at roost sites, particularly hibernacula (Brigham 1993). The largest hibernaculum discovered to date in Manitoba, by several orders of magnitude, is St. George Cave, $200 \mathrm{~km}$ north of Winnipeg. More than 20000 little browns spend each winter in that cave. This critical cave and a small area around it was declared an ecological reserve by the Province of Manitoba on 15 March 1997, after several years of effort by Willard Anderson, the authors, and other members of the Speleological Society of Manitoba. This is the most stringent legal protection a natural feature can get in this province. The Province of Manitoba, on 15 January 1996 officially declared six species of bats to be "a wild animal" under The Wildlife Act (by the Designation of Wild Animals Regulation MR 3/96), as a first step in their protection. As of December 1997, Manitoba Department of Natural Resources (now Conservation) has issued guidelines to direct all activities occurring on Crown land around the known over-wintering caves (Asmundson and Larche 1996*).

\section{Acknowledgments}

We thank our employers, the Manitoba Museum and the University of Winnipeg, for their support during the majority of the time period of this study. Additional funding was granted by the Manitoba Museum Foundation Fund. We were also substantially assisted by the 
staff of Manitoba Department of Conservation (Natural Resource Officers, Operations Branch, particularly of the Grand Rapids and Gypsumville offices, as well as Parks and Natural Areas Branch), and Manitoba Geological Survey, Department of Industry, Trade and Mines. Thanks to Tolko Industries Ltd. and the hospitable people of Grand Rapids and Gypsumville. Many family members and friends have worked with us for many hours. We would like to particularly thank Dale Brown and David Wright. Other volunteer banders and helpers over the years include Al Bisset, Melanie Dubois, Michelle Bell, Liza McClintock, Marie Voth, Lori Bilecki, Christy McDonald, Marg Rubin, Gloria Goulet, Cecile Foster, Janis Klapecki, Dennis Peristy, Kim Ottenbreit, Victoria Shemeliuk, Mike Claussen, Justin Harrison, Donna Kurt, Rick Nash, Paul Buisson, Robert Senkiw, Jocelyn Hildebrand, Marianne Setliff, Chris Caslake, Bob Gill, Darren Keam, Amy Barker, Lidi Kuiper, Lyndon Kivi, Kevin Campbell, Christine Abraham, John Fitzmaurice, Lisa Lagerge and Trapper John Christie. We thank Jim Duncan and Robert Nero for reviewing an earlier draft of this paper.

Documents Cited (marked * in text)

Asmundson, J. D., and R. A. Larche. 1996. Bat Hibernacula Management Guidelines. (unpublished manuscript) Wildlife Branch, Manitoba Department of Natural Resources. 31 pages.

\section{Literature Cited}

Banfield, A. W. F. 1974. The mammals of Canada. National Museum of Natural Sciences. University of Toronto Press. 438 pages.

Barclay, R. M. 1984. Observations on the migration, ecology and behaviour of bats at Delta Marsh, Manitoba. Canadian Field-Naturalist 98: 331-336.

Barclay, R. M. 1993. The biology of prairie bats in Proceedings of the Third Prairie Conservation and Endangered Species Workshop. Edited by G. L. Holroyd, H. L. Dickson, M. Regnier, and H. C. Smith. Provincial Museum of Alberta, Natural History Occasional Paper Number 19.

Brigham, R. M. 1993. The implications of roost sites for the conservation of Bats in Proceedings of the Third Prairie Conservation and Endangered Species Workshop. Edited by G. L. Holroyd, H. L. Dickson, M. Regnier, and H. C. Smith. Provincial Museum of Alberta, Natural History Occasional Paper Number 19.

Ecological Stratification Working Group. 1995. A National Ecological Framework For Canada. Agriculture and AgriFood Canada, Research Branch, Centre for Land and Bio- logical Resources Research and Environment Canada, State of the Environment Directorate, Ecozone Analysis Branch, Ottawa/Hull.

Holroyd, S. L., R. M. R. Barclay, L. M. Merk, and R. M. Brigham. 1994. A survey of the bat fauna of the dry interior of British Columbia. Wildlife Working Report Number WR-63, Wildlife Branch, Ministry of Environment, Lands \& Parks, B.C.

Humphries, M. M., D. W. Thomas, and J. R. Speakman. 2002. Climate-mediated energetic constraints on the distribution of hibernating mammals. Nature 418: 313-316.

Jung, T. S., and B. G. Slough. 2005. Mortality of Little Brown Bats, Myotis lucifugus, in a rodent trap in the boreal forest. Canadian Field-Naturalist 119: 589-590.

Kunz, T. H., and A. Kurta. 1988. Capture methods and holding devices. Pages 1-28 in Ecological and behavioral methods for the study of bats. Edited by T. H. Kunz. Smithsonian Institution Press, Washington, D.C. 533 pages.

McRitchie, D. W., and K. M. Monson. 2000. Caves and Karst of Manitoba's Interlake Region. Speleological Society of Manitoba, Second Edition. Winnipeg. 181 pages.

Nagorsen, D. W. 1980. Records of hibernating Big Brown Bats (Eptesicus fuscus) and Little Brown Bats (Myotis lucifugus) in northwestern Ontario. Canadian Field-Naturalist 94: 83-85.

Nagorsen, D. W., and R. M. Brigham. 1993. The Bats of British Columbia. Volume 1: The Mammals of British Columbia. Royal British Columbia Museum Handbook. UBC Press, Vancouver.

Parker, D. I., and J. A. Cook. 1996. Keen's Long-eared Bat, Myotis keenii, confirmed in southeast Alaska. Canadian Field-Naturalist 10: 611-614.

Rand, A. L. 1948. Mr. W. H. Bryenton's notes on Manitoba mammals of the Herb Lake-Flin Flon area. Canadian FieldNaturalist 62: 140-150.

Soper, J. D. 1961. The mammals of Manitoba. Canadian Field-Naturalist 75: 171-219.

Sweet G., P. Voitovice, and W. D. McRitchie. 1988. Karst Investigations in Palaeozoic Carbonates of the Grand Rapids Uplands and Southern Interlake. Geological Paper GP88-1, Province of Manitoba, Mines Branch.

Tamsitt, J. R. 1962. Mammals of the Delta Marsh region of Lake Manitoba, Canada. Canadian Field-Naturalist 76: 7176.

Tuttle, M. D. 1974. An improved trap for bats. Journal of Mammalogy 55: 475-477.

van Zyll de Jong, C. G. 1985. Handbook of Canadian mammals. Volume 2, Bats. National Museum of Natural Sciences, Ottawa, Ontario.

Received 12 August 2003

Accepted 2 October 2007 